\title{
The Influence of Cooperative Integrated Reading And Composition Model On Completing Abilities of Story Questions
}

\author{
Muhammad Ridhollah1, Muliana1 \& Mursalin*1 \\ ${ }^{1}$ Department of Mathematics Education, Universitas Malikussaleh, Aceh Utara, Indonesia \\ Corresponding Author: mursalin@unimal.ac.id
}

\begin{abstract}
This study is motivated by the low ability of students in solving story problems at MTsN 4 Aceh Utara. Based on initial observations, students have not been able to understand the story questions, namely determining what is known and asked, students have not been able to determine the formula or method used, and students have not been able to determine the final answer to the story questions, therefore this study aims to determine the effect of Cooperative Integrated Reading and Composition learning model on the ability to solve story problems in class VIII MTsN 4 Aceh Utara. This study uses a quantitative approach with a quasi-experimental research design and a posttest-only design with nonequivalent groups. The population of this study was all students of class VIII MTsN 4 North Aceh. The sample in this study was class VIII C as the control class and class VIII D as the experimental class which was obtained by purposive sampling technique. The data collection technique used in this study is a test in the form of a posttest. Data analysis was carried out to test the ability to solve story problems using the t-test because the data were normally distributed and homogeneous, the data was processed using SPSS 18 software. The normality test used the Shapiro Wilk technique, the homogeneity test used the Levene test, and the hypothesis test according to the test criteria was if significant $<0.05$, then H0 is rejected and Ha is accepted, whereas if the significant value is 0.05 , then $\mathrm{H0}$ is accepted and $\mathrm{Ha}$ is rejected. From the statistical significant results, Equal Variances assumed is 0.00 less than 0.05. Thus, the conclusion of this study is that there is an effect of the Cooperative Integrated Reading and Composition learning model on the ability to complete stories in class VIII MTsN 4 Aceh Utara.
\end{abstract}

Key words: cooperative; integrated reading; and composition; problem-solving; story problems;

\section{Introduction}

Mathematics is one of the important components in the world of education, because mathematics is one of the basics that plays an important role in studying other subjects in various disciplines. In addition, mathematics also plays an important role in science and technology. Many people think that mathematics is the most difficult field of study, but even so, we must study it because it is a means to solve problems in everyday life. According to Martini (2014: 177) that mathematics is a field of study of life, which needs to be studied because the nature of mathematics is an understanding of the patterns of change that occur in the real world and in the human mind and the relationships between these patterns holistically. Based on the above opinion, it can be concluded that mathematics is material about regular patterns, organized structures in a field of life that studies the nature of understanding the patterns of change that occur in the real world and in the human mind.

According to the Ministry of Education and Culture (Kemendikbud) 2013, the objectives of learning mathematics in the implementation of the 2013 curriculum are: Students are able to improve intellectual abilities, form students' abilities to solve problems systematically, obtain high learning outcomes, train students in communicating ideas, especially in writing works, and developing students' character. The ability to solve mathematical problems in students can be known through questions in the form of descriptions. With the questions in the form of descriptions, it can be seen the steps taken by students in solving a problem. One of the description 
questions in mathematics is a story problem.

Story questions are questions that are presented in oral or written form that illustrate activities in everyday life (Ashlock, 2003: 80). Problem stories are found in every discussion of the material because they are examples of application in everyday life. The story problem is a modification of the calculation problem made into a short story. Presentation of questions in the form of stories is one of the efforts to apply the concepts being studied in accordance with the daily experiences of students. Students' ability to solve story problems can be seen from the acquisition of learning outcomes. In addition, it can also be seen how the process of students solving the problem until they find the correct answer.

The ability of students to solve math story problems can be seen from several indicators, namely the ability to understand and capture meaning in math story problems, the ability to separate and express what is known and asked, the ability to use formulas that are in accordance with what is asked, and the ability to complete calculations with formulas. appropriate (Hudojo, 2005:27). So it can be concluded that a student is said to be able to solve story problems if he is able to understand what is asked in the problem, can change it in the form of mathematical solutions and choose the right strategy to solve it.

Related to this, the researcher conducted an interview with a mathematics teacher at MTsN 4 Aceh Utara. Based on the results of interviews with mathematics teachers at MTsN 4 Aceh Utara, it was found that MTsN 4 Aceh Utara had implemented the 2013 curriculum, some students considered mathematics to be difficult, one of the problematic materials was a two-variable linear equation system, especially in story questions, some students were not able to understand what is known and asked in the problem, students are still confused in determining the method used to solve it, sometimes in this school apply the STAD learning model on the material of the twovariable linear equation system (SPLDV).

Furthermore, to prove the truth of the results of the researcher's interview with the teacher, an identification test was carried out for class VIII F MTsN 4 Aceh Utara students, so that it could be known exactly where the problems faced by students were. The questions given by researchers to students are:

\section{Question}

On Sunday Budi went to the market with his brother to buy clothes and pants, Budi bought 3 shirts and 2 pants for Rp. 280,000,-, while her sister bought 1 shirt and 3 pants with the same brand and at the same shop for Rp. 210,000,-. How much each shirt and 1 pants cost?.

Based on the results of the identification test to 22 students of class VIII F MTsN 4 North Aceh, the results of students' answers can be seen in the image below:

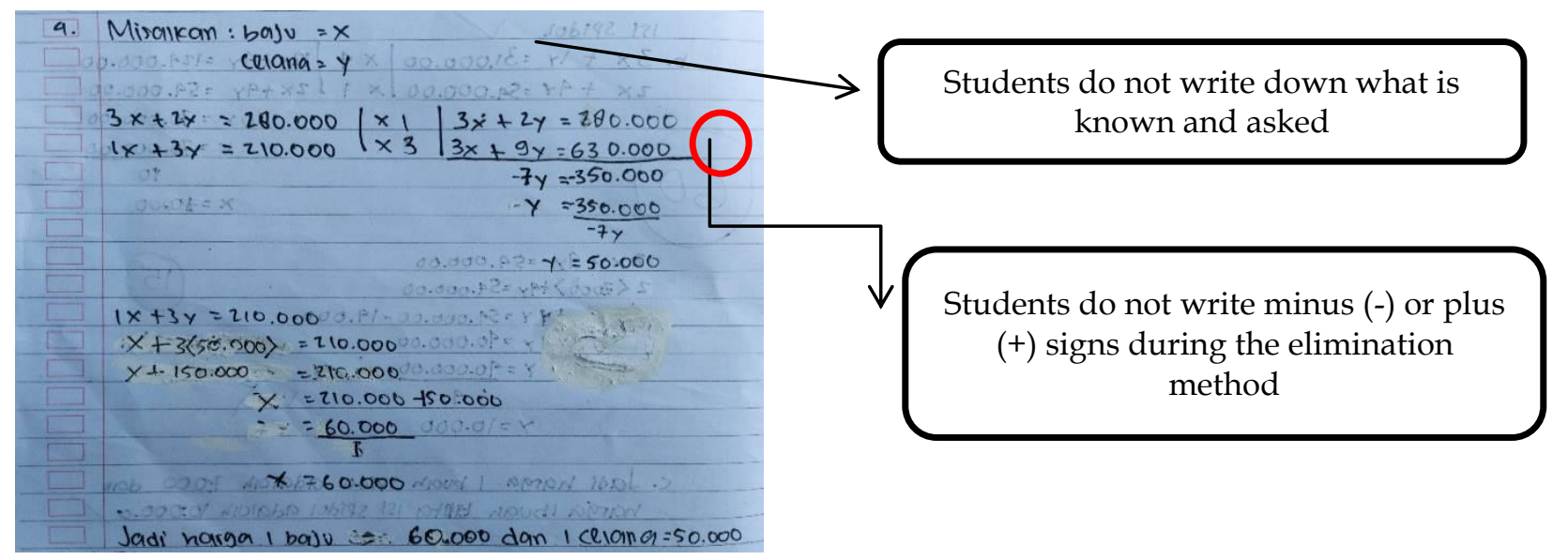

Figure 1a. Student answers 1 


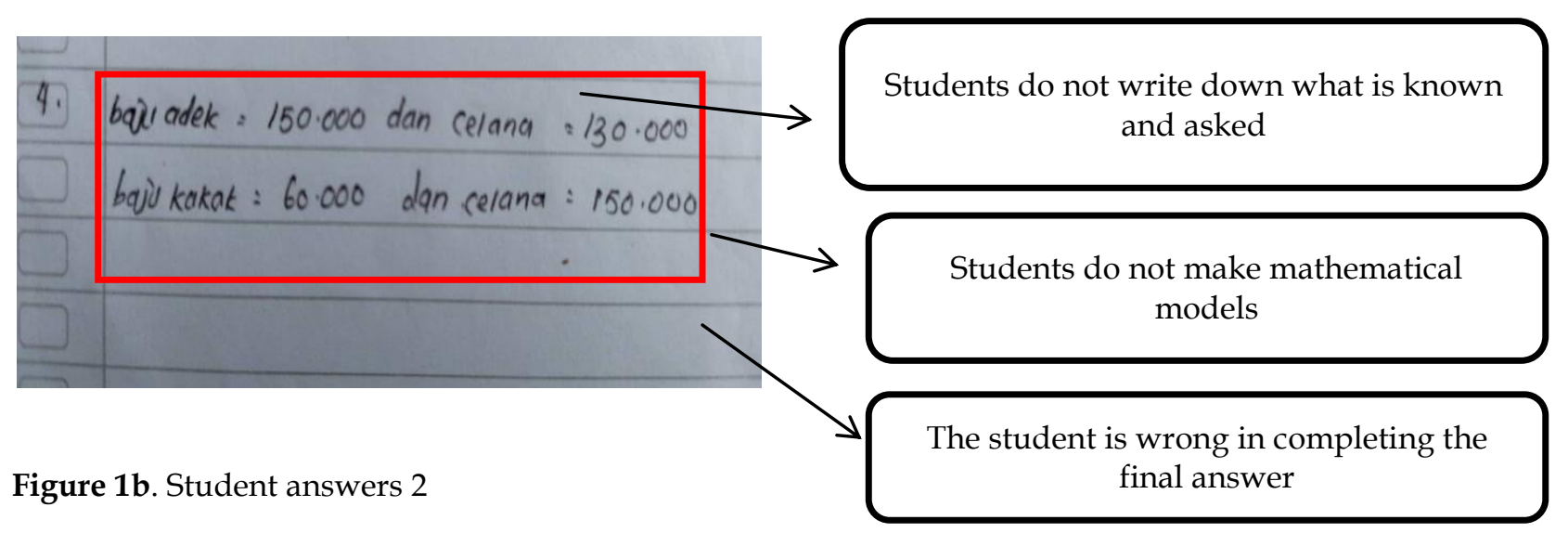

Based on the students' answers in Figure 1.1, it can be seen that students understand enough about the SPLDV material story questions by knowing the method or procedure in solving these questions. However, there are still shortcomings or errors, namely students do not write down what is known and what is asked in the question, students do not write minus (-) or plus (+) signs when using the elimination method. In Figure 1.2 students do not write down what is known and what is being asked. Students also do not make mathematical models. Students only write the final answer to the question and most students answer the questions as shown in Figure 1.2, but the final answer from students in 1.2 is not correct, because students do not understand the material and students still cannot solve story-shaped questions.

The factor of students' inability to solve story problems, namely students are less able to understand the meaning of the story problems, students have difficulty changing the form of story questions into mathematical models. This is because students find it difficult to understand the questions, do not know the steps to take first because the questions are considered too complicated. In line with Idris and Silalahi's research (2016) entitled Application of the Indonesian Realistic Mathematics Education Approach (PMRI) to Improve the Ability to Solve Story Problems in Class VII A SMP UTY, when a pre-cycle test was conducted to ensure students were able to solve story problems, it was obtained $68,4 \%$ of students do not meet the KKM and $31.6 \%$ of students have met the KKM. In addition, a study conducted by Sari and Aripin (2018), entitled Analysis of Student Errors in Solving Quadrilateral Constructed Story Problems Judging from Mathematical Problem Solving Ability for Class VII Students, found that the difficulties experienced by students were when understanding the questions because students were still confused. and have not been able to identify the elements of the story in the problem. Students are still confused in determining the strategy that will be used to solve the problems.

Not only that, research conducted by Utami, Endaryono, and Djuhartono (2018) entitled Students' Ability in Solving Math Story Problems, found that students' abilities would increase in learning, especially mathematics subjects if the teacher's teaching methods and styles were very good and easy. accepted by students, as well as how students' ability to understand or work on math story problems is how teachers can develop the learning itself, that is, teachers must always be required to be creative because this has been stated in the 2013 curriculum which is based on character and competence so that teachers must create a conducive situation and generate confidence and curiosity with the aim of increasing the ability of students to solve story problems in mathematics. So that innovative learning planning efforts are needed by using effective strategies for the ability to solve math story problems in class. One solution to improve students' ability to solve story problems is the Cooperative Integrated Reading and Composition (CIRC) learning model.

According to Slavin (2005:200) that the Cooperative Integrated Reading and Composition (CIRC) learning model is a reading and writing comprehension program at the elementary, middle, and upper levels. The Cooperative Integrated Reading and Composition (CIRC) learning model is a learning model that supports collaboration between students and between students and their teachers. Because, in CIRC learning students are grouped into small groups so that it is 
possible for students to help each other and work together until all group members understand the material being discussed. In mathematics learning, activities in the Cooperative Integrated Reading and Composition (CIRC) learning model are not only reading and writing the core of the reading, but students are required to solve story problems in the form of mathematical calculations to get the right answer.

Several studies that use the Cooperative Integrated Reading and Composition (CIRC) model, namely the research conducted by Fitriana (2010) entitled The Effect of the Cooperative Integrated Reading And Composition Type Cooperative Model on the Mathematics Problem Solving Ability of VIII Grade Students of SMP Negeri 2 Bengkalis, with the results showing an increase in students' skills in solving quadrilateral story problems. Furthermore, research conducted by Kartika (2011) entitled The Effectiveness of Application of Cooperative Learning Model Type Cooperative Integrated Reading And Composition (CIRC) on Mathematical Communication Ability in Junior High School Mathematics Learning, found the results that the application of the CIRC type cooperative learning model was more effective in improving mathematical communication skills. students both in writing and orally compared to learning using conventional learning models. Then the research conducted by Karimah (2012) entitled Learning Mathematics Cooperative Integrated Reading And Composition (CIRC) Model To Improve Mathematical Communication Skills for Grade VII Quadrilateral Materials, the results showed that there was an increase in students' communication skills, which was marked by an increase in student learning outcomes with an average - an average of 76.71 using the Cooperative Integrated Reading and Composition (CIRC) learning model.

In addition, research conducted by Ruyaliningsih (2017) entitled The Effect of Cooperative Integrated Reading And Composition (CIRC) Learning on Mathematics Learning Outcomes, shows that there is a significant effect of Cooperative Integrated Reading and Composition (CIRC) cooperative learning on mathematics learning outcomes. Not only that, the research conducted by Fahmi and Zein (2019) entitled The Effect of the Cooperative Integrated Reading And Composition Type Cooperative Model on the Mathematics Problem Solving Ability of VIII Grade Students of SMP Negeri 2 Bengkalis, with the results of the study that there is a positive effect when using the cooperative type model. CIRC on students' problem solving abilities. Based on the background above, the researchers are interested in discussing the title of the research "The Influence of Cooperative Integrated Reading And Composition Model On Completing Abilities of Story Questions".

\section{Literature Review}

The ability to solve math story problems is an activity to solve math problems that describe real events, experiences, or problems in everyday life, where the solution uses mathematical concepts and theorems (Maheasy, 2015:169). In line with this understanding, according to Irmayanti et al (2020: 240) that the ability to solve story problems is the ability of students to solve problems in the form of story questions, namely problems related to everyday life.

In addition, according to Asmiyati, Jamiah, and Ahmad (2021:2) the ability to solve story problems is the ability of students to use all the knowledge and skills they have to complete all processes in finding answers (solutions) of story questions. Meanwhile, according to Widyanti, Amaliyah, and Hartantri (2020: 64) that the ability to solve story problems is the ability or skills of students that come from within students to find solutions to problems contained in story questions related to the circumstances experienced by students in everyday life. so that the correct solution (answer) is obtained. Based on the description above, it can be concluded that the ability to solve story problems is the ability of students to be able to solve and solve problems in the form of story questions, namely questions related to problems that exist in everyday life.

The Cooperative Integrated Reading and Composition (CIRC) learning model was first developed by Stevens in 1987. This model can be categorized as integrated learning (Huda, 2014:221). The Cooperative Integrated Reading and Composition (CIRC) learning model is one of the cooperative learning models which was originally a comprehensive or comprehensive program for teaching reading, writing, and language arts for high school grades (Slavin, 2009: 201). The Cooperative Integrated Reading and Composition (CIRC) model is a learning model used to 
help students understand the meaning of the story questions given. This model is used in this study to help improve students' reading skills, so it is hoped that it will have an impact on students' skills in solving math story problems.

In this learning model, students are placed in small heterogeneous groups, consisting of 4 or 5 students. In this group there are students who are smart, moderate or weak, and each student should feel compatible with each other. The main purpose of the Cooperative Integrated Reading and Composition (CIRC) learning model is to use cooperative teams to help students learn reading comprehension skills that are widely applied (Slavin, 2009:204). According to Lestari and Yudhanegara, (2017: 49) that Cooperative Integrated Reading and Composition (CIRC) is a type of cooperative learning model that combines reading activities with other activities, such as writing, discussing, and presenting in an integrated manner. Meanwhile, according to Suyatno (2009: 68) explains that Cooperative Integrated Reading and Composition (CIRC) is an integrated composition of reading and writing in cooperative groups. Through this Cooperative Integrated Reading and Composition (CIRC) learning, it is hoped that students can improve their critical thinking, be creative, cultivate a high social sense and be able to express mathematical ideas or ideas into systematic language which in turn can improve mathematical communication skills. With the increase in students' mathematical communication, it is expected that students can solve math story problems.

\section{Methods}

This study refers to a quantitative research approach. According to Sugiyono (2017:7) quantitative methods are referred to as positivistic methods because they are based on the philosophy of positivism. This method is a scientific method because it has fulfilled scientific principles, namely concrete, objective, measurable, rational, and systematic. This method is called the quantitative method because the research data is in the form of numbers and the analysis uses statistics. While the type of research used in this study is a quasi-experimental design research. According to Sugiyono (2017: 77) this quasi-experimental design research has a control group, but cannot function fully to control external variables that affect the implementation of the experiment.

Based on the explanation above, it can be concluded that a quasi-experimental design is a type of research design that has a control group and an experimental group and is not chosen randomly. The researcher used a quasi-experimental design because in this study there were external variables that the researcher could not control. The design used in this study is a quasiexperimental design and uses a posttest-only design model with nonequivalent groups.

Table 1. Research Design

\begin{tabular}{clcl}
\hline Class & Pretest & Treatment & Posttest \\
\hline Experiment & & $\mathrm{X}$ & $\mathrm{O}_{1}$ \\
& - & & \\
\hline Control & - & & $\mathrm{O}_{2}$ \\
\hline
\end{tabular}

In this design, the experimental group and the control group were not chosen randomly. the experimental group and the control group were only given a test, namely post-test, to determine the condition of the group after treatment. In this study, the learning experimental group was carried out using the Cooperative Integrated Reading and Composition (CIRC) learning model and for the control group learning was carried out using the conventional learning model.

According to Sugiyono (2017: 80) population is a generalization area consisting of objects/subjects that have certain qualities and characteristics set by researchers to be studied and then drawn conclusions. In this study, the population was all eighth grade students at MTsN 4 Aceh Utara which consisted of 6 classes, namely VIII A, VIII B, VIII C, VIII D, VIII E, and VIII F.

According to Sugiyono (2017:81) the sample is part of the number and characteristics possessed by a certain population. Sampling in this study was taken using purposive sampling, namely a sampling technique with certain considerations (Sugiyono, 2017:85). The selection of a group of subjects in purposive sampling is based on certain characteristics that are considered to have a 
close relationship with previously known population characteristics, in other words the selected sample unit is adjusted to certain criteria that are applied based on the research objectives. To determine the control class and the experimental class, the researcher sought advice from the mathematics teacher at MTsN 4 Aceh Utara and looked at the average value of the six classes that were the population of the study. Based on the mathematics teacher's input and these scores, the researcher chose class VIII C as the control class and class VIII D as the experimental class.

The data collection technique in this study was using a test. According to Arikunto (2017: 67) a test is a tool or procedure used to find out or measure something in an atmosphere, in a way and with predetermined rules. The test in this study is a written test in the form of description questions which is used to measure students' ability to solve problems that aim to measure the ability to solve story problems as indicated by student learning outcomes in the implementation of mathematics learning. The test used in this study was a posttest with the same questions in the form of an essay description test of 5 questions.

Table 2. The indicators of students' ability to solve story problems

\begin{tabular}{|c|c|c|c|}
\hline No & $\begin{array}{l}\text { Steps to Solve Math } \\
\text { Story Problems }\end{array}$ & Indicator & Score \\
\hline \multirow[t]{5}{*}{1} & \multirow{5}{*}{$\begin{array}{l}\text { Understanding } \\
\text { Problem }\end{array}$} & Do not write known and asked. & 0 \\
\hline & & Write down known and asked but wrong. & 1 \\
\hline & & Write only one, what is known or asked. & 2 \\
\hline & & Write down known and asked not using mathematical symbols. & 3 \\
\hline & & Write down known and asked exactly and correctly. & 4 \\
\hline \multirow[t]{5}{*}{2} & \multirow{5}{*}{$\begin{array}{l}\text { Problem } \\
\text { Transformation }\end{array}$} & Unable to identify required operation or method. & 0 \\
\hline & & Created a formula or solution method, but it's wrong. & 1 \\
\hline & & The selected method is correct, but the operation is wrong. & 2 \\
\hline & & Write formulas or methods in their own language. & 3 \\
\hline & & Identify the formula or method of solving correctly and correctly. & 4 \\
\hline \multirow[t]{5}{*}{3} & \multirow[t]{5}{*}{ Process Skills } & Does not perform calculations. & 0 \\
\hline & & Didn't do the calculation but the result is correct. & 1 \\
\hline & & Perform calculations using the wrong method. & 2 \\
\hline & & Did the calculation but the result is wrong & 3 \\
\hline & & Perform calculations correctly. & 4 \\
\hline \multirow[t]{6}{*}{4} & \multirow{6}{*}{$\begin{array}{l}\text { Final } \\
\text { Writing }\end{array}$} & Do not write conclusions or answers & 0 \\
\hline & & Finally. & \\
\hline & & Draw conclusions with wrong results. & 1 \\
\hline & & Drawing conclusions but not quite right. & 2 \\
\hline & & $\begin{array}{l}\text { Draw conclusions correctly, but do not write down the appropriate } \\
\text { units. }\end{array}$ & 3 \\
\hline & & Draw conclusions correctly and correctly. & 4 \\
\hline
\end{tabular}




\section{Results and Discussion \\ Results}

This study was conducted to determine whether there is an effect of the Cooperative Integrated Reading and Composition learning model on the ability to solve story problems on the flat-sided building material, namely cubes and blocks in class VIII MTsN 4 North Aceh on 19 May to 2 June 2021. In this study used two classes, namely the experimental class as the class that received treatment through the Cooperative Integrated Reading and Composition learning model in class VIII D consisting of 22 students and the control class using the conventional model in class VIII C consisting of 22 students. The data analyzed was obtained from the post-test scores given at the end of the lesson. Before testing the hypothesis, a prerequisite test is carried out on the distribution of the two data which includes the normality test and homogeneity test. The following describes the results of testing for normality and homogeneity of the score data on the ability to solve story problems using SPSS 18 software.

Normality test aims to determine whether the data population of each variable is normally distributed or not. If the data is not normally distributed then the method used is non-parametric statistics. The normality test in this study used the Shapiro-wilk technique. Where the data that has been obtained is normally distributed if Sig. 0.05 while the data is not normally distributed if Sig. < 0.05 .

Table 3. Normality Test Results Data Ability to Solve Story Problems

\begin{tabular}{llll}
\hline Group & Shapiro-Wilk & & \\
\cline { 2 - 4 } & Statistic & Df & Sig. \\
\hline Experiment & 0,899 & 15 & 0,091 \\
\hline Control & 0,913 & 15 & 0,151 \\
\hline
\end{tabular}

From the results above, it can be seen that the significant value of the experimental class is 0.091 while the significant value of the control class is 0.151 . In accordance with the criteria for the normality test hypothesis, namely accepting $\mathrm{H0}$ if Sig. , with $=0.05$. So that the data on the test results of the ability to solve story problems can be concluded to be normally distributed. The following is a plot or graph of the normality of the experimental class and the control class:

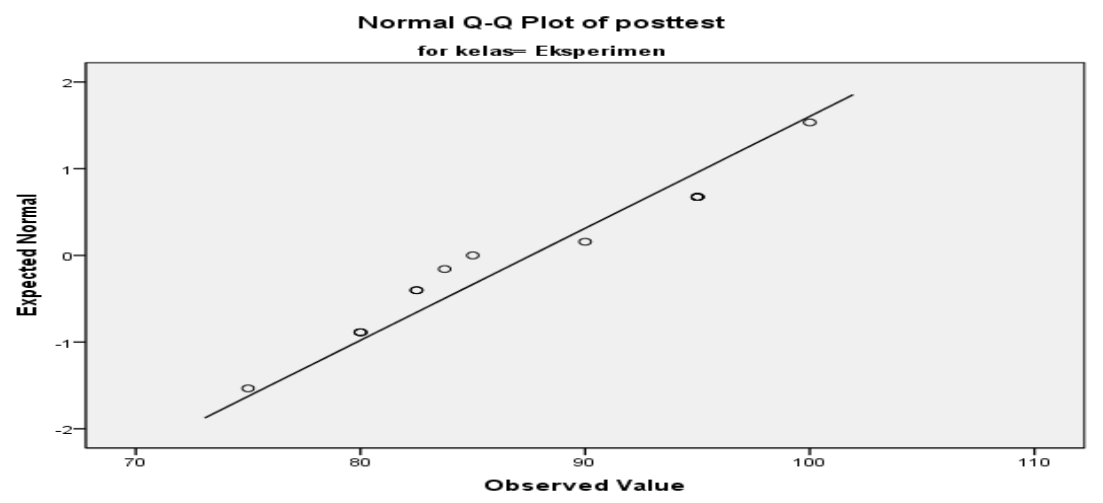

Figure 1 Plot or graph of normality of the experimental class

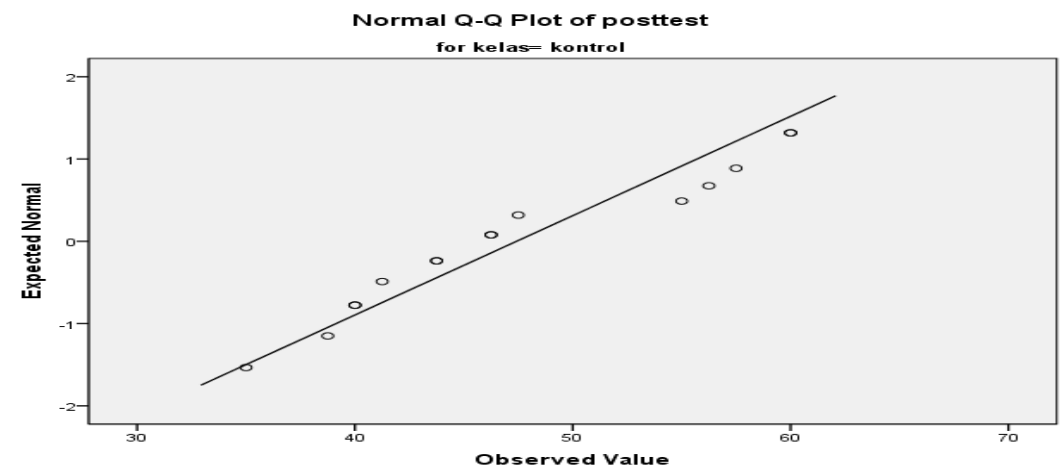


Figure 2 Plot or graph of normality control class

From the graph above, it can be concluded that the data is normally distributed because the points on the graph are very close to the line or stick to the graph, these points are data that has been tested for normality. The test data for the ability to solve story problems are normally distributed, so it can be continued with the homogeneity test. The homogeneity test aims to determine whether the post-test results of the experimental class and control class are homogeneously distributed or not. Homogeneous data if Sig. 0.05, while the data are not homogeneous if Sig. $<0.05$. The homogeneity test here is carried out using the Levene test. The following are the results of the homogeneity test on the ability test to solve story questions:

Table 4. Test of Homogeneity of Ability to Solve Story Problems

\begin{tabular}{cccc}
\hline Levene Statistic & df1 & df2 & Sig. \\
\hline 0,000 & 1 & 28 & 0,987 \\
\hline
\end{tabular}

From the table above, it can be seen that the significant value of the homogeneity test is 0.987 . In accordance with the criteria for the homogeneity test hypothesis, namely accept H0 if Sig. with = 0.05. The data from the test results of the ability to solve story problems are homogeneously distributed because the significant value is 0.05 . After the normality test and homogeneity test, it is continued with hypothesis testing or $\mathrm{t}$-test.

After the data obtained have stated that the data are normal and homogeneous, then the hypothesis test is carried out. Hypothesis testing aims to determine whether the truth of the statements or assumptions that have been made is accepted or rejected. The following is a table of hypothesis testing the ability to solve story problems:

Table 5. Results of -t-Test Ability to Solve Story Problems

\begin{tabular}{cccc}
\hline Statistic & T & Df & Sig. \\
\hline Equal variances assumed & 13,270 & 28 & 0,000 \\
\hline
\end{tabular}

From the table above, it can be seen that the statistically significant value obtained is 0.000 , so the value of sig. $<0.05$. According to the hypothesis test criteria, if the significant value is $<0.05$, then $\mathrm{H} 0$ is rejected and Ha is accepted, while if the significant value is 0.05 , then $\mathrm{HO}$ is accepted and Ha is rejected. So, it can be concluded that the hypothesis test in this study is that $\mathrm{HO}$ is rejected and $\mathrm{Ha}$ is accepted. The hypothesis of the ability to solve story problems is as follows:

$H_{0}: \mu_{A}=\mu_{B} \quad$ There is no effect of the Cooperative Integrated learning model

Reading and Composition on the ability to solve story problems.

$H a: \mu_{A} \neq \mu_{B}$ There is an influence of the Cooperative Integrated Reading and . learning model Composition on the ability to solve story problems.

It can be concluded that there is an effect of the Cooperative Integrated Reading and Composition learning model on the ability to solve story problems in class VIII MTsN 4 Aceh Utara.

\section{Discussion}

Cooperative learning model is a learning model that involves several groups in it to solve problems, cooperative learning also utilizes peers as learning resources other than teachers and other learning resources. The cooperative learning model can also develop social skills needed in group work such as leadership, communication skills, and conflict resolution skills. One of the cooperative learning models is the Cooperative Integrated Reading and Composition (CIRC) type. The Cooperative Integrated Reading and Composition (CIRC) learning model is a learning model that supports collaboration between students and between students and their teachers. Because, in CIRC learning students are grouped into small groups so that it is possible for students to help each other and work together until all group members understand the material being discussed. Activities in the Cooperative Integrated Reading and Composition (CIRC) learning model are not only reading and writing the core of the reading, but students are required to solve story problems in the form of mathematical calculations to get the right answer, therefore the Cooperative Integrated Reading and Composition learning model very suitable to see the ability to solve story problems. 
The ability to solve story problems is the ability of students to be able to solve and solve problems in the form of story questions. Questions related to problems that exist in everyday life, for example in terms of determining what is known and asked, transformation of questions, process skills, and determining the final answer to the question. Through the CIRC learning model, students are able to improve students' ability to solve math story problems, because in the CIRC learning model students are not given material directly but students are directed to find their own concepts on each topic or material. In the CIRC learning model, learning is provided through applied questions or examples and information related to students' daily lives. Thus, students are accustomed to thinking and using their mathematical abilities in drawing conclusions.

There are several things that cause students' ability to solve story problems better through the application of the Cooperative Integrated Reading and Composition (CIRC) learning model including:

1. When working on the questions contained in the LKPD students are asked to work together in their respective groups. because in solving the problems contained in the LKPD, each study group tries to solve the problem of building a flat side space without a detailed explanation from the teacher. Each group consists of students with high, medium and low abilities. Students who have high abilities are directed to help students who have medium and low abilities, so that each group member can better understand problems related to the material for building flat sides (cubes and blocks).

2. In studying this flat-sided geometry material, the teacher applies the CIRC Cooperative Integrated Reading and Composition learning model, which includes reading and writing activities. At first, the teacher asked one student from each group to read the story questions contained in the LKPD and the other members listened while observing the information contained in the questions. Next, each student in the group makes predictions and writes down information related to the story that is read. By applying the model in a lesson, it will make it easier for students to learn, because students are trained to be more thorough, active, work together and have the opportunity to express their ideas and opinions.

Based on some of the things that have been described, it shows that the CIRC model is an active learning model, so that students together in a group understand for themselves each problem presented and can draw a conclusion from the problems given. In this study, students' ability to solve story problems can be seen from the results of the post-test. The test given is an essay question consisting of 5 items where each question includes all indicators of the ability to solve story problems.

\section{Conclusion}

Based on the results of research conducted in class VIII MTsN 4 North Aceh with the material of building a flat side (cube and beam) for 3 face-to-face and 1 time Post-test, it was concluded that there was an effect of the Cooperative Integrted Reading and Composition (CIRC) learning model. on the ability to solve story problems compared to learning with conventional models, this is obtained through the results of the student's final test (post-test). The average post-test results of the experimental class students using the Cooperative Integrated Reading and Composition (CIRC) learning model were higher than the control class using the conventional model, namely the experimental class 87.58 and the control class 47.41 . According to the test criteria, if the value of sig $<0.05$, then reject H0. From the statistical significant results, Equal Variances assumed is 0.00 less than 0.05 , so reject $\mathrm{H} 0$ and accept $\mathrm{Ha}$, which means that there is an effect of the Cooperative Integrated Reading and Composition learning model on the ability to complete stories in class VIII MTsN 4 North Aceh students. Based on the conclusions above, looking at the obstacles experienced by researchers when conducting research can be presented as suggestions which are useful for further research improvements, namely: for schools and teachers in particular, should be able to use the CIRC learning model as an alternative in the learning process, especially in ability to solve math story problems and it is hoped that further researchers will assess student activity using activity sheets so that student activity using this model can be seen. 


\section{References}

Arikunto. (2017). Dasar-Dasar Evaluasi Pendidikan. Jakarta. Bumi Aksara.

Ashlock. (2003). Guiding Each Child's Learning of Mathematics. Colombus: Bell Company

Asmiyati, D., M., Jamiah, Y. Ahmad, D., B. (2021). Productive Dispoation Ditinjau Dari Kemampuan Siswa Dalam Menyelesaikan Soal Cerita Pada Materi Perbandingan. Jurnal Pendidikan Dan Pembelajaran Khatulistiwa, 10(1): 1-8.

Fahmi, M., Zein, M. (2019). Pengaruh Model Kooperatif Tipe Cooperative Integrated Reading And Composition Terhadap Kemampuan Pemecahan Masalah Matematika siswa kelas VIII SMP Negeri 2 Bengkalis. Intrusctional Development Journal (IDJ), 2(1): 11-16.

Fitriana, S. (2010). Penerapan Model Pembelajaran Cooperative Tipe CIRC (Cooperative Integrated Reading And Composition) Untuk Meningkatkan Keterampilan Siswa Dalam Menyelesaikan Soal Cerita Pada Pokok Bahasan Segiempat. Skripsi, Universitas Muhammadiyah Surakarta. Tidak diterbitkan.

Huda, M. (2014). Model- Model Pengajaran dan Pembelajaran. Yogyakarta. Pustaka Pelajar.

Hudojo, H. (2005). Pengembangan Kurikulum dan Pembelajaran Matematika edisi revisi II. Malang: Universitas Negeri Malang (UM Press).

Idris, I., Silalahi, D., K. (2016). Penerapan Pendekatan Pendidikan Matematika Realistik Indonesia (PMRI) untuk Meningkatkan Kemampuan Menyelesaikan Penyelesaian Soal Cerita Pada Kelas VII A SMP UTY. Jurnal EduMatSains, 1(1): 73-82.

Irmayanti, Rohani, Pasaribu, L., H., Rahma, I., F., dan Nazliah, R. (2020). Analisis Kemampuan Menyelesaikan Soal Cerita Ditinjau Dari Kemampuan Penalaran Dan Komunikasi Matematis Siswa. Jurnal Numeracy, 7(2): 240-254.

Karimah, S. (2013). Pembelajaran Matematika Model Cooperative Integrated Reading And Composition (CIRC) Untuk Meningkatkan Kemampuan Komunikasi Matematis Materi Segiempat kelas VII. Jurnal Ilmiah Pendidikan Matematika, 1(2): 136-143.

Kemendikbud. (2013). Kerangka Dasar dan Struktur Kurikulum 2013. Jakarta: Kemendikbud

Lestari dan Yudhanegara. (2017). Penelitian Pendidikan Matematika. Bandung: PT Refika Aditama.

Mahmudah, S. (2015). Peningkatan Ketrampilan Menyelesaikan Soal Cerita Matematika Menggunakan Media Kartu Kerja Pada Siswa Kelas II SDN Purworejo Kecamatan Kandat Kabupaten Kediri. Jurnal PINUS, 1(2): 165-173.

Martini, J. (2014). Kesulitan Belajar: Perspektif, Asesmen, dan Penanggulangannya. Bogor: Ghalia Indonesia.

Ruyaliningsih. (2017). Pengaruh Pembelajaran Cooperative Integrated Reading And Compotition (CIRC) Terhadap Hasil Belajar Matematika. Jurnal Kajian Pendidikan Matematika, 02(02): 211218.

Sari, A., R., Aripin, U. (2018). Analisis Kesalahan Siswa Dalam Menyelesaikan Soal Cerita Bangun Datar Segiempat Ditinjau Dari Kemampuan Pemecahan Masalah Matematika Untuk Siswa Kelas VII. Jurnal Pembelajaran Matematika Inovatif, 1(6): 1135-1142.

Slavin, R., E. (2005). Cooperative Learning. Bandung. Nusa Media.

Slavin, R., E. (2009). Cooperative Learning (Teori, Riset, Praktik). Bandung. Nusa Media.

Sugiyono. (2017). Metode Penelitian Kuantitatif, Kualitatif dan RED. Bandung. Alfabeta.

Suyatno. (2009). Menjelajah Pembelajaran Inovatif. Surabaya. Masamedia Buana Pustaka.

Utami, R., W., Endaryono, B., T., Djuhartono., T. (2018). Kemampuan Peserta Didik Dalam Menyelesaikan Soal Cerita Matematika. Faktor Jurnal Ilmiah Kependidikan, 5(3): 187-192.

Widyanti, P., Amaliyah, A., Hartantri, S., D. (2020). Hubungan Antara Minat Baca Dengan Kemampuan Menyelesaikan Soal Cerita Matematika Kelas III SDN Tanah Tinggi 1 Kota Tanggerang. Indonesian Journal Of Elementary Education, 2(1): 62-74. 